Mycologia, 104(3), 2012, pp. 777-784. DOI: 10.3852/11-334

(C) 2012 by The Mycological Society of America, Lawrence, KS 66044-8897

\title{
The phylogenetic position of Haasiella (Basidiomycota, Agaricomycetes) and the relationships between $H$. venustissima and $H$. splendidissima
}

\author{
Alfredo Vizzini ${ }^{1}$ \\ Dipartimento di Biologia Vegetale, Università degli \\ Studi di Torino, Viale Mattioli 25, I-10125, Torino, \\ Italy \\ Giovanni Consiglio \\ Via Ronzani 61, I-40033 Casalecchio di Reno \\ (Bologna), Italy \\ Ledo Setti \\ Via C. Pavese 1, I-46029 Suzzara (Mantova), Italy \\ Enrico Ercole \\ Dipartimento di Biologia Vegetale, Università degli \\ Studi di Torino, Viale Mattioli 25, I-10125, Torino, \\ Italy
}

\begin{abstract}
Based on a combined ITS-LSU rDNA analysis, the omphalinoid genus Haasiella is shown to be part of the Hygrophoroid clade and sister to Hygrophorus. H. venustissima and H. splendidissima are conspecific; $H$. splendidissima is the tetrasporic/ clamped and heterothallic form of $H$. venustissima.

Key words: Agaricales, apomictic taxa, Chrysomphalina, Hygrophoraceae, Omphalina, omphalinoid fungi
\end{abstract}

\section{INTRODUCTION}

In recent years phylogenetic analyses based on rDNA molecular characters have provided fresh conceptual insight into the taxonomy of taxa traditionally assigned to Omphalina Quél. s.l. (small agarics with a convex to deeply umbilicate pileus, central stipe, thin context, decurrent lamellae, white spore print and thin-walled unornamented spores (Bigelow 1970; Singer 1986; Norvell et al. 1994; Lutzoni 1997; Redhead et al. 2002a, b). Molecular-phylogenetic research in fact has shown that the genus Omphalina s.l. is a polyphyletic and heterogeneous assemblage (the so-called omphalinoid taxa, Redhead 1986; Lutzoni 1997; Redhead et al. 2002a, b), which in turn has spawned the recognition of several generic segregates of Omphalina. These taxa are distributed across three major clades: (i) the Hygrophoroid clade (Arrhenia Fr., Chrysomphalina Clémençon, Chromosera Redhead, Ammirati \& Norvell, Lichenomphalia

Submitted 10 Oct 2011; accepted for publication 22 Nov 2011.

${ }^{1}$ Corresponding author. E-mail: alfredo.vizzini@unito.it
Redhead, Lutzoni, Moncalvo \& Vilgalys, Melanomphalia M.P. Christ. p.p. [Lutzoni and Vilgalys 1995, Lutzoni 1997; Redhead et al. 2002a; Aime et al. 2005; Matheny et al. 2006; Lawrey et al. 2009; Binder et al. 2010; Ovrebo et al. 2011]); (ii) the Hymenochaetoid clade (Blasiphalia Redhead, Cantharellopsis Kuyper, Contumyces Redhead, Moncalvo, Vilgalys \& Lutzoni, Gyroflexus Raithelh., Loreleia Redhead, Moncalvo, Vilgalys \& Lutzoni, Rickenella Raithelh. [Moncalvo et al. 2000, 2002; Redhead et al. 2002b; Palice et al. 2005; Larsson et al. 2006; Larsson 2007]); (iii) the Tricholomatoid clade (Omphalina s.s. including the type species $O$. pyxidata [Bull.] Quél. [Vizzini et al. 2011a] and Omphalina giovanellae [Bres.] Singer [Moreno et al. 2007]).

The rare omphalinoid species belonging to the genus Haasiella Kotl. \& Pouzar (typified by $H$. venustissima [Fr.] Kotl. \& Pouzar) have not been studied molecularly so far. They are characterized by monomitic basidiomes with a pink-orange pigmentation due to an accumulation of carotenoid pigments (Arpin 1966; Arpin and Fiasson 1971; Tyler 1971; Valadon 1976), a lignicolous habitat, a yellow-pinkish spore-print, a gelatinized pileipellis, a thickening hymenium, elongated basidia, a bidirectional lamella trama and metachromatic spores in cresyl blue (Kotlaba and Pouzar 1966; Horak 1968; Clémençon 1982, 2004; Kost 1986; Kuyper 1986, 1995; Singer 1986; Reijnders and Stalpers 1992; Norvell et al. 1994). Haasiella has been reported only from Europe thus far. The only two recognized species, $H$. venustissima and $H$. splendidissima Kotl. \& Pouzar, are distinct on the basis of the number of sterigmata and presence/absence of clamp connections.

Based on a combined ITS and LSU rDNA molecular analyses, the aim of the paper was (i) to infer the phylogenetic position of Haasiella within the Agaricomycetes Doweld and (ii) to investigate whether the morphologically closely related $H$. venustissima and H. splendidissima are conspecific (syntaxic) or distinct taxa.

\section{MATERIALS AND METHODS}

Herbarium specimens were checked microscopically to determine whether they were correctly classified (see Consiglio et al. 2012). Herbarium abbreviations are according to Thiers (2011). Authorial citations follow the Index Fungorum Authors of Fungal Names (http://www. indexfungorum.org/authorsoffungalnames.htm). 
TABLE I. Haasiella and Omphalina collections used for molecular analyses

\begin{tabular}{|c|c|c|c|}
\hline \multirow[b]{2}{*}{ Species } & \multicolumn{2}{|c|}{ GenBank accession numbers } & \multirow[b]{2}{*}{ Source, country, date and collector } \\
\hline & ITS & LSU & \\
\hline Haasiella venustissima & JN944393 & JN944394 & $\begin{array}{l}\text { E.C. 08191, ITALY, Rio Secco (Mombaroccio, PU), 15/10/ } \\
\text { 2008, leg. G. Consiglio \& M. Maletti }\end{array}$ \\
\hline Haasiella splendidissima 1 & JN944395 & JN944396 & JVG1071013 - 1, SPAIN, Pardines, 13/10/2007, leg. J. Vila \\
\hline Haasiella splendidissima 2 & JN944397 & - & $\begin{array}{l}\text { WU 5654, AUSTRIA, Kärnten, Kraig, Wimitzbach-Tal, 26/09/ } \\
\text { 1986, leg. R. Schütz \& A. Hausknecht }\end{array}$ \\
\hline Haasiella splendidissima 3 & JN944398 & JN944399 & $\begin{array}{l}\text { Herbarium Roux n. 3666, MOLDAVIAN REPUBLIC, } \\
\text { National Park Codrii, 29/09/2001, leg. S. Manic }\end{array}$ \\
\hline Haasiella splendidissima 4 & JN944400 & JN944401 & $\begin{array}{l}\text { Herbarium Roux n. 4044, FRANCE, Gresse-en-Vercors } \\
\text { (Isère), 6/10/2003, leg. V. Dumas }\end{array}$ \\
\hline Haasiella splendidissima 5 & - & - & $\begin{array}{l}\text { PR } 613781 \text { (holotype), SLOVAKIA, Banská Bystrika, 27/09/ } \\
\text { 1965, leg. Z. Pouzar, F. Kotlaba \& D.A. Reid }\end{array}$ \\
\hline Omphalina pyxidata & JN944402 & JN944403 & $\begin{array}{l}\text { TO AV98, ITALY, Torino, Pinerolo, 10/10/2010, leg. A. } \\
\text { Vizzini }\end{array}$ \\
\hline
\end{tabular}

DNA extraction, PCR amplification and DNA sequencing.Genomic DNA was isolated from $1 \mathrm{mg}$ of herbarium specimens (TABLE I) with the DNeasy Plant Mini Kit (QIAGEN, Milan, Italy) according to the manufacturer's instructions. Universal primers ITS1F/ITS4 were used for the ITS region amplification (White et al. 1990; Gardes and Bruns 1993) and primers LR0R/LR7 (Vilgalys and Hester 1990; Vilgalys lab unpubl, http://www.botany.duke.edu/ fungi/mycolab) for the LSU amplification. Amplification reactions were performed in a PE9700 thermal cycler (Perkin-Elmer, Applied Biosystems) following Vizzini et al. (2011b). PCR products were purified with the AMPure XP kit (Beckman) and sequenced by DiNAMYCODE srl (Turin, Italy) and Macrogen Inc. (Seoul, Republic of Korea). Sequencing reactions were performed in both forward and reverse directions on the PCR products. Sequences were assembled and edited with the phred/phrap/consed software suite. The sequences were submitted to GenBank (accession numbers are reported in TABLE I, FIG. 1), and the alignments and phylogenetic tree are available at TreeBASE (www.treebase.org) under accession number S12079.

Sequence alignment and phylogenetic analysis.-The sequences obtained were checked and assembled with Geneious 5.3 (Drummond et al. 2010) and compared to those available in GenBank (http://www.ncbi.nlm.nih.gov/ Genbank/) with the BLASTN algorithm. Based on BLASTN results, sequences were selected according to the outcomes of recent phylogenetic studies on Agaricales Underw. (Matheny et al. 2006; Binder et al. 2010; Ovrebo et al. 2011; Seitzman et al. 2011). A combined analysis of ITS and LSU sequences was carried out with sequences from the same strain or specimen. Gymnopus dryophilus (Bull.) Murrill (DQ241781 and AY640619) was used as outgroup taxon. The alignments were generated with MAFFT (Katoh et al. 2002) with default conditions for gap openings and gap extension penalties. The sequences alignment, its manual adjustment and the best-fit models estimation follow Vizzini et al. (2011b). The GTR + G substitution model and a partitioned matrix were used in all analyses.
Molecular-phylogenetic analyses were performed with Bayesian inference (BI), maximum likelihood (ML) and maximum parsimony (MP) approaches. BI using Monte Carlo Markov chains (MCMC) was carried out with MrBayes 3.1.2 (Huelsenbeck and Ronquist 2001). Four incrementally heated simultaneous MCMCs were run 10000000 generations under model assumption. Trees were sampled every 1000 generations resulting in an overall sampling of 10001 trees. The burn-in was evaluated with Tracer 1.5 (Rambaut and Drummond 2007); the first $25 \%$ trees was discarded. For the remaining trees a majority rule consensus tree showing all compatible partitions was computed to obtain estimates for Bayesian posterior probabilities (BPP). Branch lengths were estimated as mean values over the sampled trees. Only BPP values exceeding $50 \%$ are reported in the trees. This Bayesian analysis was repeated three times, always with random starting trees and random starting values for model parameters to test the independence of the results from the revisiting of the prior topologies during chain growth (Huelsenbeck et al. 2002). ML estimation was performed through RAxML 7.0.4 (Stamatakis 2006) with 1000 bootstrap replicates (Felsenstein 1985) using the GTRGAMMA (in both analyses) algorithm to perform a tree inference and search for a good topology. Support values from bootstrapping runs (MLB) were mapped on the globally best tree with the $-f$ a option of RAxML and -x 12345 as a random seed to invoke the novel rapid bootstrapping algorithm. MP analysis was performed with PAUP* $4.0 \mathrm{~b} 10$ (Swofford 2002) using the heuristic search mode with 100 random addition sequence replicates and tree bisection reconnection (TBR) branch swapping but keeping only 10 trees per replicate to discover possible islands of maximum parsimony. All character states were treated as unordered and equally weighted. Gaps were treated as missing data. Branch robustness was estimated by nonparametric bootstrapping (Felsenstein 1985) with 500 replicates with 10 random addition replicates per bootstrap. Only bootstrap values exceeding $50 \%$ are visualized in the tree (MPB). Support values for major clades that are supported in BI, ML and MP are visualized in the resulting tree. Pairwise percent identity 


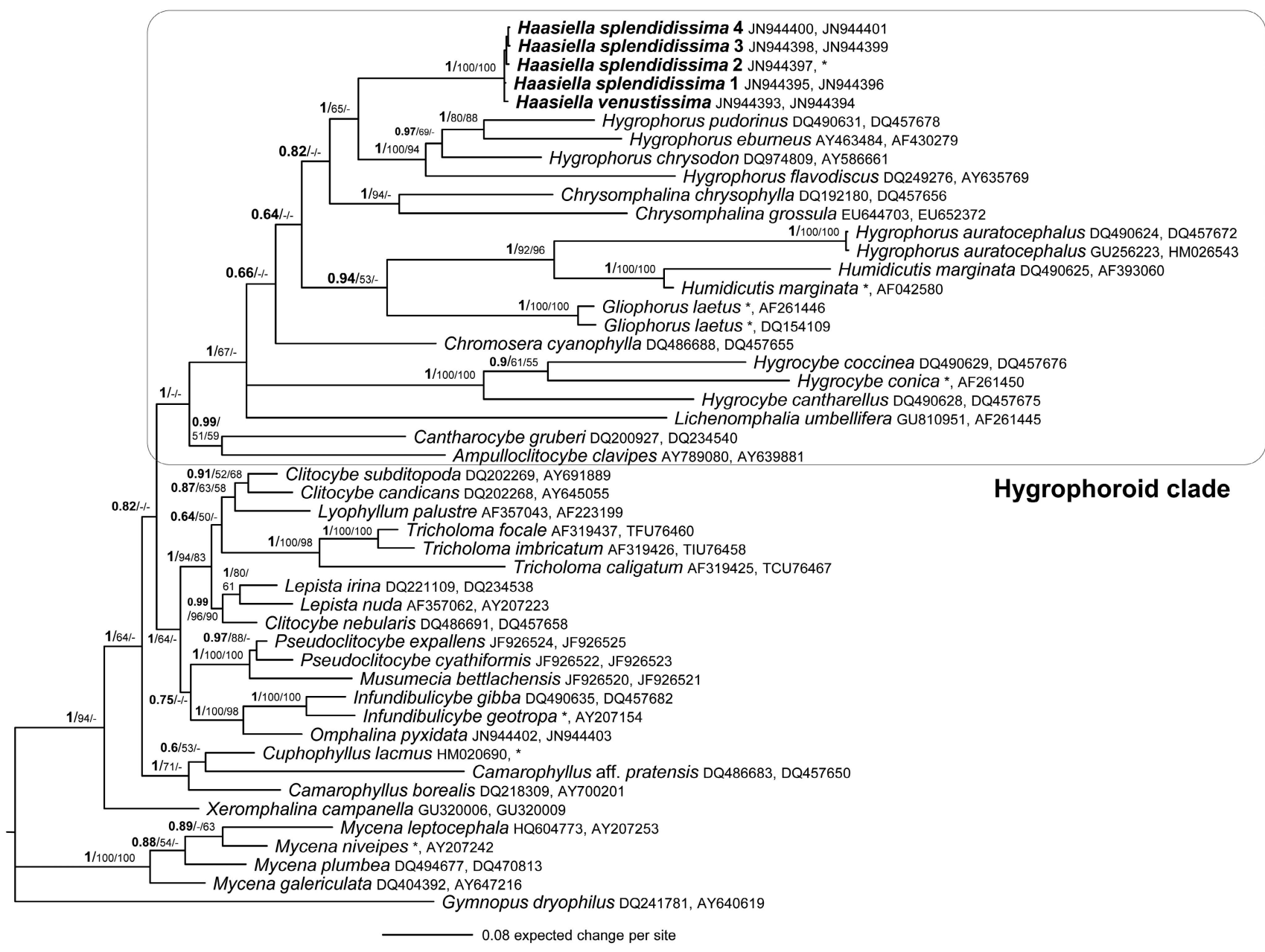

FIG. 1. Bayesian phylogram obtained from the combined ITS-LSU sequence alignment. Support values for clades that are supported in either the Bayesian (posterior probabilities values $=\mathrm{BPP})$, maximum likelihood $(\mathrm{ML}$ bootstrap percentage $=$ MLB) and maximum parsimony (MP bootstrap percentage $=\mathrm{MPB}$ ) analyses are indicated. BPP greater than 0.50 and MLB/ MPB greater than $50 \%$ are above branches. Numbers (1-5) refer to the H. splendidissima collections (TABLE I).

values for the Haasiella sequences (see results) were calculated with MEGA 5.0 (Tamura et al. 2011).

\section{RESULTS}

Amplification and sequencing of the ITS and LSU rDNA regions were successful for all the specimens selected for molecular study (TABLE I), with the exception of $H$. splendidissima 5 (type specimen was too old). No amplification of the LSU region was obtained from the H. splendidissima 2 specimen. The PCR product was 589-675 bp (ITS) and 1064-1085 bp (LSU). The ITS data matrix comprises a total of 42 sequences (including 36 from GenBank). This dataset is 1070 base pairs long and contains 572 (53.5\%) variable sites. Of these, $399(44.0 \%)$ are parsimony informative. The LSU data matrix comprises a total of 46 sequences (including 41 from GenBank). This dataset is 1451 base pairs long and contains 394
(27.2\%) variable sites. Of these, $255(17.6 \%)$ are parsimony informative. The combined dataset comprises a total of 48 taxa (including 42 from GenBank) and is 2521 base pairs long. The topologies of the combined ITS and LSU Bayesian, maximum likelihood and maximum parsimony trees are congruent, and all the three analyses have reported high support values for most branches (FIG. 1). Haasiella clearly belongs to the Hygrophoroid clade. The genera that were recognized in the Hygrophoroid clade by Matheny et al. (2006), Binder et al. (2010), Ovrebo et al. (2011) and Seitzman et al. (2011) also belong to this clade in our analyses, with high bootstrap support, with the exception of the genus Cuphophyllus (Donk) Bon that falls outside the clade (FIG. 1). Haasiella sequences form a distinct clade (BPP 0.82) together with Hygrophorus Fr. and Chrysomphalina Clémençon sequences. Haasiella clusters as sister to Hygrophorus (BPP 1 and MLB 65\%), and Chrysomphalina 
is basal to this clade. The four $H$. splendidissima collections and the one $H$. venustissima collection cluster together into a unique, strongly supported clade (BPP 1, MLB 100\% and MPB 100\%). The five Haasiella ITS sequences and the four Haasiella LSU sequences show a pairwise percent identity of 99.3 and 99.9, respectively. The Haasiella/Hygrophorus/Chrysomphalina clade is sister to the clade consisting of Gliophorus/Humidicutis and Hygrophorus auratocephalus (Ellis) Murrill.

\section{DISCUSSION}

Generic placement, Haasiella/Chrysomphalina connections and phylogenetic position.-Published as Agaricus (Clitocybe) venustissimus Fr. (Fries 1861) the taxon later was considered a Clitocybe (Karsten 1879), an Omphalia (Quélet 1886), a Hygrophoropsis (Haas 1958), a Gerronema (Singer 1961, 1964; Haas 1965), a "Chrysomphalina" (Haas 1962, invalid genus) and also an Omphalina s.l. by Lange (1981, 1992) and Ludwig (2001). However Kotlaba and Pouzar (1966) had established the genus Haasiella to accommodate $A$. venustissimus and the new species $H$. splendidissima. Singer $(1975,1986)$ recognized Haasiella but only as a section of his heterogeneous genus Gerronema, while Kühner (1980), Clémençon (1982), Moser (1983), Kost (1986), Kuyper (1986, 1995), Norvell et al. (1994), Romagnesi (1995), Bon (1997), Horak (2005) and Elborne (2008) accepted it as a distinct genus.

Haas (1962) considered Agaricus venustissimus and Agaricus chrysophyllus Fr. to be very closely related and congeneric, due to the colored spore print, and invalidly established the genus "Chrysomphalina Haas" (typified by C. chrysophylla). These generic affinities among the two taxa were highlighted again by Raithelhuber (1973) with the new combination Haasiella chrysophylla (Fr.) Raithelh. Clémençon (1982) validated the genus Chrysomphalina including the type, C. chrysophylla (Fr.) Clémençon, and Gerronema strombodes (Berk. \& Mont.) Singer but excluding Haasiella as a related but distinct genus.

Haasiella shares with Chrysomphalina a lignicolous habitat, a yellow-pinkish spore print, a thickening hymenium (production of basidia of different lengths on short subhymenial elements (Kühner 1928; Clémençon 1982, 2004; Kost 1986), a bidirectional hymenial trama, elongated basidia and the presence of carotenoid pigments (Arpin 1966; Fiasson and Bouchez 1968; Arpin and Fiasson 1971; Gill and Steglich 1987), even though in Haasiella there is a majority of $\gamma$-carotenoids while in Chrysomphalina they are outnumbered by $\beta$-carotenoids (Fiasson and Bouchez 1968, Kühner 1980). Haasiella differs mainly in having thick-walled metachromatic spores and a slightly gelatinized pileipellis (Kost 1986, Norvell et al. 1994). The two species of Haasiella so far recognized are said by some authors to be strictly terrestrial (e.g. Kost 1986, Norvell et al. 1994), but many collections were found on stumps or wood debris (Kotlaba and Pouzar 1966; Baiano and Forno 1983; Døssing 1980; Romagnesi 1995; Vila and Caballero 2007; Roux 2006; Dam 2007; Elborne 2008; Eyssartier and Roux 2011; Consiglio et al. 2012). Haasiella species are probably saprotrophic on wood and woody debris, according to these data and our observations.

In the pre-molecular era the Haasiella/Chrysomphalina genus pair was regarded as belonging to either the Tricholomataceae R. Heim ex Pouzar (Kühner 1980; Moser 1983; Singer 1986; Kuyper 1986, 1995; Bon 1997; Horak 2005) or, due to the presence of carotenoids and elongated basidia, to the Cantharellaceae J. Schröt. (Fiasson and Bouchez 1968; Norvell et al. 1994; Romagnesi 1995, 1996), a family well circumscribed also on the basis of these pigments (Fiasson 1968; Fiasson et al. 1970; Mui et al. 1998). Romagnesi (1996) even established the tribus Chrysomphalineae in the Cantharellaceae to accommodate the gilled agarics with carotenoids (Haasiella, Chrysomphalina and Phyllotopsis E.-J. Gilbert \& Donk ex Singer; see Arpin 1966; Fiasson and Bouchez 1968; Fiasson 1969).

Recent DNA studies (Lutzoni 1997; Moncalvo et al. 2000, 2002; Redhead 2002a; Matheny 2006; Binder et al. 2010; Ovrebo et al. 2011) have highlighted that Chrysomphalina chrysophylla is closely related to the Hygrophoraceae Lotsy of the Hygrophoroid clade. Depending on taxon sampling, genetic loci studied and phylogenetic analysis methods used, Chrysomphalina has been resolved as sister to Hygrocybe (Fr.) P. Kumm. (Redhead et al. 2002a), sister to Hygrophorus (Moncalvo 2000, 2002, Binder et al. 2010), allied to other hygrophoroid genera (Lutzoni 1997), allied to Hygrocybe and Chromosera Redhead, Ammirati \& Norvell (Matheny et al. 2006) and as sister to Gliophorus laetus (Ovrebo et al. 2011).

Based on the above molecular results, Knudsen and Vesterholt (2008), in Funga Nordica, classified Chrysomphalina in the Hygrophoraceae and Haasiella also was placed in the same family due to its morphological and pigment affinities with Chrysomphalina.

Our data support that Haasiella is a genus distinct from Chrysomphalina and that it belongs to the Hygrophoraceae where it is sister to Hygrophorus (FIG. 1). Hygrophorus shares with Haasiella the distant lamellae and elongated basidia but differs in the absence of carotenoid pigments (Gill and Steglich 1987; Lübken et al. 2006; Teichert et al. 2008), the non-metachromatic spores, the bilateral hymenophoral trama and the strictly terrestrial basidiomes (Singer 1986, Bon 1990). 
Sporal metachromacy in Haasiella is a feature that is not shared by any other member of the Hygrophoroid clade. The character also is sparingly present in other agaricoid, gilled genera, being so far known only in the Leucocoprineae Singer (Macrolepiota Singer, Leucoagaricus Locq. ex Singer, Leucocoprinus Pat., Chlorophyllum Massee [Singer 1986]) in the Agaricoid clade (Matheny et al. 2006) and for Tricholoma cookeanum Bertault \& Malençon (Bon 1991) in the Tricholomatoid clade (Matheny et al. 2006).

Gliophorus Herink and Humidicutis (Singer) Singer (+ Hygrophorus auratocephalus) are sister to the clade formed by Chrysomphalina, Haasiella and Hygrophorus (FIG. 1).

Interspecific relationships. - Haasiella venustissima is a rarely collected and infrequently illustrated species (Haas 1965; Nothnagel 1974; Døssing 1980; Baiano and Forno 1983; Kelderman 1996; Moser and Jülich 1997; Chiaffi and Surault 1996b; Gyosheva 2000; Vila and Caballero 2007; Dam 2007; Consiglio et al. 2012), and it has been included in the red data lists of rare and threatened macromycetes of several European countries (e.g. Senn-Irlet et al. 2007; Laurent-Dargent 2009; Karasch and Hahn 2009). It is well characterized by having mono- and bisporic basidia and lacking clamp connections. According to the karyological studies by Lamoure (in Kühner 1980), Kost (1986) and Chiaffi and Surault (1996a), the spores, young basidia and subhymenial hyphae are mononucleate, a feature indicating an apomictic way of life. Such a life cycle is not uncommon in Agaricales (Whitehouse 1949; Lamoure 1957, 1960; Kühner 1980; Kües et al. 2011) and known for species in Mycena (Kühner 1938, Lamoure 1955), Omphalina s.l. (Lamoure 1968, 1969), Coprinus s.l. (Lange 1952), Agaricus (Volkova et al. 2003, Kamzolkina et al. 2006), Favolaschia (Vizzini et al. 2009) and Hygrocybe (Boertmann 2010).

Haasiella splendidissima differs in having tetrasporic basidia and clamp connections and in being putatively heterothallic (Kotlaba and Pouzar 1966; Horak 1968; Clémençon 1982). It originally was described from Slovakia (Kotlaba and Pouzar 1966) and then collected again only five times, from Spain (Vila and Caballero 2007), France (Roux pers comm), the Republic of Moldova (Roux 2006), Austria (Moser and Jülich 1997) and also from Switzerland (Roffler and Ardüser 2010). Since the original description some authors have recognized H. splendidissima as a distinct species (Singer 1975, 1986; Clémençon 1982; Moser 1983; Kuyper 1995; Chiaffi and Surault 1996a; Bon 1997; Horak 2005; Elborne 2008), others have regarded it as a taxon subordinate to $H$. venustissima (Ludwig 2001 as Omphalina venustissima var. splendidissima [Kotl. \& Pouzar] E. Ludw.; Roux 2008 as $H$. venustissima var. splendidissima [Kotl. \& Pouzar] P. Roux); still others only as an informal tetrasporic variant of $H$. venustissima deserving no formal taxonomic rank (Romagnesi 1995, Vila and Caballero 2007). The latter taxonomic decision was based possibly on the fact that Vila and Caballero (2007) collected the specimens of $H$. splendidissima at the same site where they had found specimens of $H$. venustissima.

Our phylogenetic analysis highlights that all the Haasiella sequences (eight of H. splendidissima and two of $H$. venustissima) are almost identical. The five ITS sequences display a pairwise percent identity value of 99.3. According to this value and accepting an intraspecific ITS variability lower than $3 \%$ (Nilsson et al. 2008), $H$. splendidissima and $H$. venustissima could be considered conspecific, $H$. splendidissima being only a tetrasporic strain (population) of $H$. venustissima with a heterothallic life cycle. A similar situation was demonstrated for Agaricus bisporus (J.E. Lange) Imbach, where three different types of life cycles are present in cross-fertile populations (Kamzolkina et al. 2006).

The bisporic and non-clamped populations of $H$. venustissima seem to be relatively more common and widespread than the tetrasporic ones due to their apomictic (homothallic) way of life. Murtagh et al. (2000) suggested that these apomictic mechanisms might be an adaptation to circumstances in which opportunities for outbreeding arise infrequently with the consequent removal of the time-consuming necessity of encountering a suitable mate.

\section{ACKNOWLEDGMENTS}

We most sincerely thank A. Hausknecht (Vienna, Austria), J. Holec (Prague, Czech Republic), J. Vila (Barcelona, Spain) and P. Roux (Sainte-Sigolène, France) for sending herbarium collections.

\section{LITERATURE CITED}

Aime MC, Vilgalys R, Miller OK Jr. 2005. The Crepidotaceae (Basidiomycota, Agaricales): phylogeny and taxonomy of the genera and revision of the family based on molecular evidence. Am J Bot 92:74-82, doi:10.3732/ ajb.92.1.74

Arpin N. 1966. Recherches chimiotaxinomiques sur les champignons. Sur la présence de caroténoïdes chez Clitocybe venustissima. Compt Rend Hebd Séances Acad Sci 262:347-349.

_ Fiasson JL. 1971. The pigments of Basidiomycetes: their chemotaxonomic interest. In: Petersen RH, ed. Evolution in the higher Basidiomycetes: an international symposium. Knoxville: Univ. Tennessee Press. p 63-98. 
Baiano G, Forno S. 1983. Haasiella venustissima (Fr,) Kotl. \& Pouz. Boll Gr Micol Bres 26:181-182.

Bigelow HE. 1970. Omphalina in North America. Mycologia 62:1-32, doi:10.2307/3757709

Binder M, Larsson K-H, Matheny PB, Hibbett DS. 2010. Amylocorticiales ord. nov. and Jaapiales ord. nov.: early diverging clades of Agaricomycetidae were dominated by corticioid forms. Mycologia 102:865-880, doi:10. 3852/09-288

Boertmann D. 2010. The genus Hygrocybe. 2nd revised ed. Fungi of northern Europe. Vol 1. Copenhagen: Svampetryk, Danish Mycological Society. 200 p.

Bon M. 1990. Flore mycologique d'Europe 1. Les Hygrophores. Doc Mycol, mém. hors-sér. 1:1-99.

- 1991. Flore mycologique d'Europe 2. Les Tricholomes et ressemblants. Doc Mycol, mém. hors-sér. 2:1-163.

- 1997. Flore mycologique d'Europe 4. Les Clitocybes, Omphales et ressemblants. Doc Mycol, mém. hors-sér. 4:1-181.

Chiaffi M, Surault J-L. 1996a. Une espèce rare et remarquable, Haasiella venustissima (Fr.) Kotl. \& Pouz. Bull Soc Mycol Fr 112:127-134.

—, 1996b. Haasiella venustissima (Fr.) Kotl. \& Pouz. Bull Soc Mycol Fr 112 Atlas, planche 312.

Clémençon H. 1982. Kompendium der Blätterpilze Europäische omphalinoide Tricholomataceae. Zeitschr Mykol 48:195-237.

- 2004. Cytology and plectology of the Hymenomycetes. Bibliotheca Mycol 199:1-488.

Consiglio G, Setti L, Vizzini A. 2012. Contributo alla conoscenza del genere Haasiella. Rivista di Micologia (In press).

Dam N. 2007. Het ongelooflijke superprachttrechtertje tussen tuinafval. Coolia 50:96.

Døssing L. 1980. Førtste fund af Haasiella venustissima i Danmark. Svampe 1:15-18.

Drummond AJ, Ashton B, Buxton S, Cheung M, Cooper A, Duran C, Field M, Heled J, Kearse M, Markowitz S, Moir R, Stones-Havas S, Sturrock S, Thierer T, Wilson A. 2010. Geneious 5.3. Available at http://www.geneious. com/

Elborne SA. 2008. Haasiella Kotl. \& Pouzar. In: Knudsen H, Vesterholt J, eds. Funga Nordica-Agaricoid, boletoid and cyphelloid genera. Copenhagen, Denmark: Nordsvamp. $192 \mathrm{p}$.

Eyssartier G, Roux P. 2011. Le guide des champignons France et Europe. Paris: Belin. 1120 p.

Felsenstein J. 1985. Confidence limits on phylogenies: an approach using the bootstrap. Evolution 39:783-791, doi: $10.2307 / 2408678$

Fiasson JL. 1968. Les caroténoïdes des Basidiomycètes, survol chimio- taxinomique. Lyon, France: Thèse spécialité. 84 p.

— 1969. Recherches chimiotaxinomiques sur les champignons. Les caroténoïdes de Phyllotopsis nidulans (Pers. ex Fr.) Sing. (Agaricales). Compt Rend Hebd Séances Acad Sci 268:786-788.

— Bouchez MP. 1968. Recherches chimiotaxinomiques sur les champignons. Les carotènes de Omphalia chrysophylla Fr. Compt Rend Hebd Séances Acad Sci 266:1379-1381.

—_- Petersen RH, Bouchez MP, Arpin N. 1970. Recherches chimiotaxinomiques sur les champignons XIV. Contribution biochimique à la connaissance taxonomique de certains champignons cantharelloïdes et clavarioïdes. Rev Mycol 34:357-364.

Fries EM. 1861. Hymenomycetes novi vel minus cogniti, in Suecia 1852-1860 observati. Öfvers Kongl Vetensk-Ak 18:19-34.

Gardes M, Bruns TD. 1993. ITS primers with enhanced specificity for basidiomycetes-application to the identification of mycorrhizae and rusts. Mol Ecol 2:113-118, doi:10.1111/j.1365-294X.1993.tb00005.x

Gill M, Steglich W. 1987. Pigments of fungi (Macromycetes). Prog Chem Org Nat Prod. 51:1-317.

Gyosheva M. 2000. New and rare macromycetous taxa to Bulgaria. Phytol Balcan 6:283-288.

Haas H. 1958. Clitocybe venustissima Fr. in Stuttgart wiederentdeckt. Zeitschr Pilzk 4:9-12.

- 1962. Die systematische Stellung von Clitocybe venutissima Fries. Zeitschr Pilzk 28:12-13.

—. 1965. Gerronema venustissimum (Fr.) Sing. Syn. Hygrophoropsis venustissima (Fr.) Haas. Schw Zeitschr Pilzk 43:19-21.

Horak E. 1968. Synopsis generum Agaricalium. Die Gattungstypen der Agaricales. Beitrage zur Kryptogamenflora der Schweiz. Bd. 13. Bern: Buchler, Wabern. 741 p. 2005. Röhrlinge und Blätterpilze in Europa 6. München: Elsevier Spektrum Akademischer Verlag. $575 \mathrm{p}$.

Huelsenbeck JP, Ronquist F. 2001. MrBayes: Bayesian inference of phylogenetic trees. Bioinformatics 17: 754-755, doi:10.1093/bioinformatics/17.8.754

—_, Larget B, Miller RE, Ronquist F. 2002. Potential applications and pitfalls of Bayesian inference of phylogeny. Syst Biol 5:673-688.

Kamzolkina OV, Volkova VN, Kozlova MV, Pancheva EV, Dyakov YT, Callac P. 2006. Karyological evidence for meiosis in the three different types of life cycles existing in Agaricus bisporus. Mycologia 98:763-770, doi:10.3852/mycologia.98.5.763

Karasch P, Hahn CH. 2009. Rote Liste gefährdeter Großpilze Bayerns. Bayerisches Landesamt für Umwelt (LfU). 108 p.

Karsten PA. 1879. Rysslands, Finlands och den Skandinaviska halföns Hattsvampar. Förra Delen: Skifsvampar. Bidrag till Kännedom Finlands Natur Folk 32:1-571.

Katoh K, Misawa K, Kuma K, Miyata T. 2002. MAFFT: a novel method for rapid multiple sequence alignment based on fast Fourier transform. Nucl Acids Res 30: 3059-3066, doi:10.1093/nar/gkf436

Kelderman PH. 1996. Haasiella venustissima (Fr.) Kotl. \& Pouz. AMK Mededelingen 96:47-48.

Knudsen H, Vesterholt J, eds. 2008. Funga Nordica. Copenhagen, Denmark: Nordsvamp. 965 p.

Kost G. 1986. Morphologie, Anatomie und Systematik carotinoidhaltiger Blätterpilze. Ber Deutsch Bot Ges 99:43-58. 
Kotlaba F, Pouzar. 1966. Haasiella, a new Agaric genus and H. splendidissima sp. nov. Česká Mykol 20:135-140.

Kües U, James TY, Heitman J. 2011. Mating type in Basidiomycetes: unipolar, bipolar, and tetrapolar patterns of sexuality. In: Pöggeler S, Wöstemeyer J, eds. The Mycota XIV-evolution of fungi and fungal-like organisms. Berlin: Springer-Verlag. p 97-160.

Kühner R. 1928. (Planches). Pl. 24 (Leucopaxillus amarus), 25 (Lentinus variabilis), 26 (Stropharia squamosa), 28 (Omphalia chrysophylla). Bull Soc Mycol Fr 44.

— 1938. Le genre Mycena. Paris: Le Chevalier. 710 p. - 1980. Les Hyménomycètes agaricoïdes. Bull. Soc. Linn. Lyon 49, num. spéc. 1-1027.

Kuyper TW. 1986. Generic delimitation in European omphalinoid Tricholomataceae. La Famiglia delle Tricholomataceae. Atti del Convegno internazionale, 10-15 Sep 1984, Borgo val di Taro, Italy. Atti del Centro studi per la flora mediterranea 6:83-104.

. 1995. Haasiella Kotl. \& P. In: Bas C, Kuyper TW, Noordeloos ME, Vellinga EC, eds. Flora Agaricina Neerlandica. Vol 3. Rotterdam, the Netherlands: A.A. Balkema. p 63-64.

Lamoure D. 1955. La race bisporique de Mycena iodiolens Lundell est-elle homothalle? Rev Mycol 20:30-36.

— 1957. Parthénogénèse ou amphithallie chez trois formes bisporiques de Basidiomycètes. Rev Mycol 22: 285-290.

- 1960. Recherches cytologiques et expérimentales sur l'amphithallie et la parthénogénèse chez les Agaricales. Evolution nucléaire dans la baside des formes bisporiques. Lyon, France: Thèse spécialité. 117 p.

- 1968. Parthenogénèse chez Omphalina ericetorum (Pers. ex Fr.) M. Lange et deux espèces affines. Compt Rend Hebd Séances Acad Sci, Sér D 266:1499-1500.

— 1969. Évolution nucléaire dans la baside de formes parthénogénétiques tétrasporiques de trois espèces d'Omphalina (Agaricales). Bull Soc Myc Fr 85:247-249.

Lange M. 1952. Species concepts in the genus Coprinus. Dansk Bot Ark 14:1-140.

- 1981. Typification and delimitation of Omphalina Quél. Nord J Bot 1:691-696, doi:10.1111/j.1756-1051. 1981.tb01424.x

—. 1992. Omphalina Quél. In: Hansen L, Knudsen H, eds. Nordic Macromycetes. Vol. 2. Copenhagen, Denmark: Nordsvamp. p 170-174.

Larsson K-H. 2007. Rethinking the classification of corticioid fungi. Mycol Res 111:1040-1063, doi:10.1016/ j.mycres.2007.08.001

— Redhead SA. 2006. Hymenochaetales: a molecular phylogeny for the hymenochaetoid clade. Mycologia 98:926-936, doi:10.3852/mycologia.98.6.926

Laurent-Dargent J. 2009. La Liste Rouge des champignons (macromycètes) rares ou menacés de Lorraine. Nancy, France: Thèse spécialité. 116 p.

Lawrey JD, Lücking R, Sipman HJM, Chavez JL, Redhead SA, Bungartz F, Sikaroodi M, Gillevet PM. 2009. High concentration of basidiolichens in a single family of agaricoid mushrooms (Basidiomycota: Agaricales:
Hygrophoraceae). Mycol Res 113:1154-1171, doi:10. 1016/j.mycres.2009.07.016

Lübken T, Arnold N, Wessjohann L, Bottcher C, Schmidt J. 2006. Analysis of fungal cyclopentenone derivatives from Hygrophorus spp. by liquid chromatography/ electrospray-tandem mass spectrometry. J Mass Spectrom 41:361-371, doi:10.1002/jms.996

Ludwig E. 2001. Pilzkompendium Band 1. Beschreibungen. Eching, Germany: IHW-Verlag. 758 p.

Lutzoni F. 1997. Phylogeny of lichen- and non-lichenforming omphalinoid mushrooms and the utility of testing for combinability among multiple datasets. Syst Biol 46:373-406, doi:10.1093/sysbio/46.3.373

— - Vilgalys R. 1995. Omphalina (Basidiomycota, Agaricales) as a model system for the study of coevolution in lichens. Crypt Bot 5:1-81.

Matheny PB, Curtis JC, Hofstetter V, Aime MC, Moncalvo JM, Ge ZW, Yang ZL, Slot JC, Ammirati JF, Baroni TJ, Bougher NL, Hughes KW, Lodge DJ, Kerrigan RW, Seidl MT, Aanen DK, DeNitis M, Daniele GM, Desjarden DE, Kropp BR, Norvell LL, Parker A, Vellinga EC, Vilgalys R, Hibbett DS. 2006. Major clades of Agaricales: a multilocus phylogenetic overview. Mycologia 98:982-995, doi:10.3852/mycologia.98.6.982

Moncalvo J-M, Lutzoni F, Rehner SA, Johnson J, Vilgalys R. 2000. Phylogenetic relationships of agaric fungi based on nuclear large subunit ribosomal DNAsequences. Syst Biol 49:278-305, doi:10.1093/sysbio/49.2.278

_, Vilgalys R, Redhead SA, Johnson JE, James TY, Aime MC, Hofstetter V, Verduin SJW, Larsson E, Baroni TJ, Thorn RG, Jacobsson S, Clémençon H, Miller OK Jr. 2002. One hundred seventeen clades of euagarics. Mol Phylogenet Evol 23:357-400, doi:10.1016/ S1055-7903(02) 00027-1

Moreno G, Contu M, Ortega A, Platas G, Peláez F. 2007. Molecular phylogenetic studies show Omphalia giovanellae represents a new section of Clitopilus (Agaricomycetes). Mycol Res 111:1399-1405, doi:10.1016/ j.mycres.2007.09.009

Moser M. 1983. Die Röhrlinge und Blätterpilze. 5th ed. Kleine Kryptogamenflora, Band II b/2. Stuttgart: G. Fischer. 533 p.

— Jülich W. 1997. Farbatlas der Basidiomyceten, Lief. 15. III. Haasiella 1. Stuttgart: G. Fischer.

Mui D, Feibelman T, Bennett JW. 1998. A preliminary study of the carotenoids of some North American species of Cantharellus. Int J Plant Sci 159:244-248, doi:10.1086/ 297545

Murtagh GJ, Dyer PS, Crittenden PD. 2000. Reproductive systems-sex and the single lichen. Nature 404:564, doi:10.1038/35007142

Nilsson RH, Kristiansson E, Ryberg M, Hallenberg N, Larsson K-H. 2008. Intraspecific ITS variability in the kingdom Fungi as expressed in the international sequence databases and its implications for molecular species identification. Evol Bioinf 4:193-201.

Norvell LL, Redhead SA, Ammirati JF. 1994. Omphalina sensu lato in North America 1-2. 1: Omphalina wynniae and the genus Chrysomphalina. 2: Omphalina sensu Bigelow. Mycotaxon 50:379-407. 
Nothnagel P. 1974. Der Orangerote Wachstrichtering (Haasiella venustissima) bei Weissenfels. Mykol MittBl 18:67-70.

Ovrebo CL, Lodge DJ, Aime MC. 2011. A new Cantharocybe from Belize with notes on the type of Cantharocybe gruberi. Mycologia 103:1102-1109, doi:10.3852/10-360

Palice Z, Schmitt I, Lumbsch HT. 2005. Molecular data confirm that Omphalina foliacea is a lichen-forming basidiomycete. Mycol Res 109:447-451, doi:10.1017/ S0953756204002199

Quélet L. 1886. Enchiridion fungorum in Europa media et praesertim in Gallia vigentium. Lutetiae. 352 p.

Raithelhuber J. 1973. Zur Abgrenzung der Gattungen Gerronema, Omphalina, Clitocybe und Haasiella. Metrodiana 4:61-72.

Rambaut A, Drummond AJ. 2007. Tracer 1.4. [Available at http://beast.bio.ed.ac.uk/Tracer].

Redhead SA. 1986. Mycological observations 17-20: nomenclatural notes on some omphaloid genera in Canada, Chrysomphalina, Rickenella, Gerronema, Omphalina. Acta Mycol Sin Suppl 1:297-304.

___ Lutzoni F, Moncalvo JM, Vilgalys R. 2002a. Phylogeny of agarics: partial systematics solutions for core omphalinoid genera in the Agaricales (Euagarics). Mycotaxon 83:19-57.

—_ Moncalvo J-M, Vilgalys R, Lutzoni F. 2002b. Phylogeny of agarics: partial systematics solutions for bryophilous omphalinoid agarics outside of the Agaricales. Mycotaxon 82:151-168.

Reijnders AFM, Stalpers JA. 1992. The development of the hymenophoral trama in the Aphyllophorales and the Agaricales. Stud Mycol 34:1-109.

Roffler U, Ardüser H. 2010. Der Pilz des Monats 5. Haasiella splendidissima Kotl. \& Pouzar. Schw Zeitschr Pilzk 88: 90-93.

Romagnesi H. 1995. Prodrome à une flore analytique des hyménomycètes agaricoïdes III. Fam. Cantharellaceae Schroeter. Doc Mycol 25:417-424.

- 1996. Validations. Bull Soc Myc Fr 112:134-135.

Roux P. 2006. Mille et un champignons. Sainte-Sigolène, France: Éditions Roux. 1223 p.

- 2008. Novitates 2. Combinaisons nouvelles. Doc Mycol 34:41-44.

Seitzman BH, Ouimette A, Mixon RL, Hobbie EA, Hibbett DS. 2011. Conservation of biotrophy in Hygrophoraceae inferred from combined stable isotope and phylogenetic analyses. Mycologia 103:280-290, doi:10. 3852/10-195

Senn-Irlet B, Bieri G, Egli S. 2007. Liste rouge-champignons supérieurs. Liste rouge des espèces menacées en Suisse, édition 2007. Office fédéral de l'environnement OFEVet par l'Institut fédéral de recherches sur la forêt, la neige et le paysage WSL Berne. 94 p.

Singer R. 1961. Diagnoses fungorum novorum Agaricalium II. Sydowia 15:45-83.

- 1964. Die Gattung Gerronema. Nova Hedwigia 7:53-92.

- 1975. The Agaricales in modern taxonomy. 3rd ed. Vaduz, Switzerland: Cramer. 912 p.
1986. The Agaricales in modern taxonomy. 4th ed. Koenigstein, Germany: Koeltz Scientific Books. 981 p.

Stamatakis A. 2006. RAxML-VI-HPC: maximum likelihoodbased phylogenetic analyses with thousands of taxa and mixed models. Bioinformatics 22:2688-2690, doi:10. 1093/bioinformatics/btl446

Swofford DL. 2002. PAUP* 4.0b10: phylogenetic analyses using parsimony (*and other methods). Sunderland, Massachusetts: Sinauer Associates.

Tamura K, Peterson D, Peterson N, Stecher G, Nei M, Kumar S. 2011. MEGA5: molecular evolutionary genetics analysis using maximum likelihood, evolutionary distance and maximum parsimony methods. Mol Biol Evol. (In press). doi:10.1093/molbev/msr121.

Teichert A, Lübken T, Schmidt J, Kuhnt C, Huth M, Porzel A, Wessjohann L, Arnold N. 2008. Determination of beta-carboline alkaloids in fruiting bodies of Hygrophorus spp. by liquid chromatography/electrospray ionisation tandem mass spectrometry. Phytochem Anal 19:335-341, doi:10.1002/pca.1057

Thiers B. 2011. [continuously updated]. Index Herbariorum: a global directory of public herbaria and associated staff. New York Botanical Garden's Virtual Herbarium. http://sweetgum.nybg.org/ih/, doi: - Either ISSN or Journal title must be supplied.

Tyler VE Jr. 1971. Chemotaxonomy in the Basidiomycetes. In: Petersen RH, ed. Evolution in the higher Basidiomycetes: an international symposium. Knoxville: Univ. Tennessee Press. p 29-62.

Valadon LRG. 1976. Carotenoids as additional taxonomic characters in fungi: a review. Trans Br Mycol Soc 67:115, doi:10.1016/S0007-1536(76)80001-0

Vila J, Caballero F. 2007. Haasiella venustissima y Melanophyllum eyrei, dos interesantes hongos de la Peninsula Iberica. Micol Veg Med 22:19-28.

Vilgalys R, Hester M. 1990. Rapid genetic identification and mapping of enzymatically amplified ribosomal DNA from several Cryptococcus species. J Bacteriol 172:4238-4246.

Vizzini A, Zotti M, Mello A. 2009. Alien fungal species distribution: the study case of Favolaschia calocera. Biol Invasions 11:417-429, doi:10.1007/s10530-008-9259-5

, Contu M, Ercole E. 2011a. Musumecia gen. nov. in the Tricholomatoid clade (Basidiomycota, Agaricales) related to Pseudoclitocybe. Nord J Bot 29, first published 20 Oct 2011. DOI: 10.1111/j.1756-1051.2011.01169.x

_- Angelini C, Ercole E. 2011b. A new Neopaxillus species (Agaricomycetes) from the Dominican Republic, and the status of Neopaxillus within the Agaricales. Mycologia 104, first published 20 Sep 2011. DOI: 10.3852/ $10-345$

Volkova VN, Kamzolkina OV, Kozlova MV, Dyakov YT. 2003. A comparative cariology of Agaricus bisporus strains with different types of life cycle. Mikol Fitopatol 37:30-41.

White TJ, Bruns TD, Lee S, Taylor J. 1990. Amplification and direct sequencing of fungal ribosomal RNA genes for phylogenetics. In: Innis MA, et al., eds. PCR protocols. London: Academic Press. p 315-322.

Whitehouse HLK. 1949. Multiple-allelomorph heterothallism in the Fungi. New Phytol 48:212-244, doi:10.1111/ j.1469-8137.1949.tb05120.x 